\title{
Literacy and the media in the Fiji Islands
}

\section{ABSTRACT}

In a previous article in this journal (Geraghty 2001), I pointed out that while Fijian and Fiji Hindi are by far the most commonly used languages in everyday interaction in Fiji, the language of the media is almost exclusively English. There are historical reasons for this, but now that colonialism is past, nominally at least, the question arises as to whether it is possible to promote vernacular media that more accurately reflect actual language use, and hence better serve the people of Fiji. In this commentary, I point to the potential problems with vernacular media in Fiji, specifically Fijian, and suggest ways to overcome them.

\section{PAUL GERAGHTY \\ University of the South Pacific}

TYPICAL popular assessment of language use in Fiji is the follow
ing: 'Basically, the Fijians speak Fijian, the Indians speak Hindi -
and everybody speaks English.' (Douglas \& Douglas, 1987, p. 255). Granted that this is a generalisation from a guide-book, and that the first two propositions can be sustained, nevertheless the claim that everybody in Fiji speaks English - much touted by officialdom in luring tourists and investors - requires some serious qualification.

The ethnic make-up of Fiji is approximately 51 per cent Fijian, 44 per cent Indian, and 5 per cent others, out of a total population of some 800,000. More than 99 per cent of Fijians have a variety of Fijian as their first language. Impressionistically, for maybe 40 per cent of these the mother tongue is Standard Fijian - a figure that has increased dramatically over the past 20 or so years, as a result of rapid urban drift. (Standard Fijian is sometimes referred to as 'Bauan Fijian'). The remaining 60 per cent speak one (or more) 
of the 300 or so non-standard varieties of Fijian, usually with Standard Fijian as a second or third language.

Fijian (usually Standard Fijian) is also the mother tongue of some other communities, including those of Solomon Island origin (approximately 8000) and many of Rotuman, Kiribati and other Pacific Islander origin. Most kailoma (people of mixed European and Fijian ancestry) also speak Fijian.

The population of Indian origin, mostly descendants of labourers who were brought to Fiji by the British colonial authorities between 1879 and 1916, all speak Fiji Hindi, which is a variety based on a number of related Hindi dialects of north-east India, principally Awadhi and Bhojpuri (Siegel, 1987, p. 189). There are slight regional differences, with the Fiji Hindi of Vanualevu being particularly distinct. Gujarati is still spoken by the closeknit and influential Gujarati community, mostly descendants of free immigrants who came to set up businesses in the early twentieth century, and Punjabi is likewise still spoken. The other minority Indian languages have been losing ground to Fiji Hindi, and now Tamil, Telegu and Malayalam have very few speakers, while Nepalese is no longer spoken.

Other minority languages include Rotuman (4000) spoken on Rotuma and various parts of Fiji, mostly urban; several dialects of Cantonese (2000 and increasing) spoken in urban and market-gardening areas, mostly on the main island of Vitilevu; Banaban (3000), closely related to Kiribati, mostly on Rabe; and Vaitupu Tuvaluan (1000) mostly on Kioa.

Those who speak a variety of English as their mother tongue probably do not constitute more than 1 per cent of the population. Maybe half of these are expatriate workers, mostly from Australia and New Zealand. The resident English-speaking community numbers only in the hundreds. The remainder are mostly urban members of the kailoma, Rotuman and other communities who no longer use their mother tongue and speak a variety of English which is peculiar to Fiji, called Fiji Pidgin English (or simply Fiji English) (Geraghty, 2000). This has become a first language for maybe 2000 people.

Two other pidgins are spoken in Fiji, neither of which has become a creole (first language): Pidgin Fijian and Pidgin Fiji Hindi. These are often used as lingua francas, particularly in rural areas. Most citizens of Fiji are at least bilingual, and many speak three or more different languages. There are no figures as to how many speak English as a second language, and to what degree of competence. Visitors often get an inflated idea of the prevalence of 
English because those who work in the tourism industry need it for their jobs, and because of its predominance in official use and in the media.

The current (1997) constitution attempts to promote the use of vernacular languages by declaring that the public has a right to be served by government in all three major languages (English, Fijian and Hindi). Unfortunately, very little has been done to carry out this noble intention and citizens of Fiji still believe that most government services are only available in English, and if they are unable to speak or write English, then they are not entitled to them. My observation after working for the Fiji government for many years is that many Fijian civil servants spend a great deal of time filling in official forms, writing letters, and so on, in English, on behalf of their friends and relatives; and that most of these forms and letters go on to be read and processed by Fijian-speakers!

In education, the system inherited from colonial times is based on that of New Zealand, where the use of Maori used to be punished, in the belief that it was bad for the children's education. Speaking Fijian (or Fiji Hindi) anywhere in the school is still punishable. Fijian is only taught in the first three years, and only in some schools. Thereafter it is sometimes taught as a subject, but the syllabus is amateurish and inconsistent, and deals almost exclusively with traditional domains - there is no concept of Fijian being a language used in the modern world. Many politicians and community leaders have over the past fifty years urged that schools teach all children to speak Fijian and Hindi, but this has yet to happen (Geraghty, 1997).

For more details of language use in Fiji, see Geraghty, 1984 and Mangubhai \& Mugler, 2003.

\section{Languages of the media}

In this commentary I will concentrate on Fijian, but would like to briefly comment on Fiji Hindi. The situation for Fiji Hindi is rather different, because it is not taught in schools, has no accepted writing system, and is stigmatised by most of its own speakers, who consider it 'broken Hindi'. Undoubtedly Fiji Hindi could become a language of the media, but the first requirement is a major shift of attitude among its speakers.

The disparity between the overwhelming use of vernacular languages in everyday interaction and their scarcity in the media is far more marked in the print media than in radio broadcasting. Every week there are 21 newspapers in English, two in Fijian, and one in Hindi (Asian Hindi rather than Fiji Hindi,

50 PACIFIC JOURNALISM REVIEW 11 (1) 2005 
so not the vernacular). So, while over 50 per cent of the population are firstlanguage speakers of Fijian, less than 10 per cent of the print media are in Fijian - considerably less if the relative size of the newspapers is taken into account, Fijian language newspapers being less than half the size of their English-language counterparts.

Local radio is more representative. There are currently three Fijian-language stations, three in Hindi (but again mostly Asian Hindi, not Fiji Hindi), and four in English (mostly of Fiji English).

Television is a special case: being a monopoly run by an expatriate and urban elite, it almost totally ignores local languages. Less than 10 per cent of the total content is local (Robie, 2004, p. 114), and most of that is in English, with programmes in Fijian totalling slightly over one hour per week, and none at all in Fiji Hindi.

In addition to being linguistically elitist, the Fiji media also give undue prominence to 'cultural' activities that are alien to the country. For example, we are told every February 14th that 'couples all over Fiji are going to their favourite restaurant to celebrate Valentine's Day', when I would be surprised if even 0.1 per cent of the population indulged in this quaint foreign custom. Similarly, every year there is a posed photograph of schoolchildren cheering that purports to show them 'celebrating' the end of the school year, when typically in Fiji it is a day when few attend school, those that do clean the school, and feel either tired, indifferent, or sad at parting with their friends. At the same time, real cultural events, such as the Veisisivi Sere (annual Methodist Church Choir Competition), which holds over half the population - not only Methodists - riveted for a week every August, receive very little coverage.

\section{Fiji English in the media}

I have noted above that the English used in the media is usually a variety of Fiji English. This is an inevitable result of the journalists being themselves speakers of Fiji English. For many years now I have been studying The Fiji Times (the most widely read English daily) and noting instances of non-standard spelling, lexicon and syntax. ${ }^{1}$ Two main observations can be made: that most spelling mistakes are the result of the phonology of Fiji English; and that there are many words, expressions, and constructions (well over one thousand on file) which are peculiar to the Fiji media, most of which are taken directly from Fiji English. 


\section{THE INDIGENOUS PUBLIC SPHERE}

The phonology (sound system) of Fiji English is identical to that of contemporary Standard Fijian - probably as a result of it having been forged by Fijian speakers. Many sounds that are distinct in Standard English are not distinct in Fiji English - for example, the words spelt 'this' and 'these' are pronounced the same, as 'theece'. So when a local journalist comes to write the word they pronounce 'theece', because of their limited literacy in English they tend not to know which of the two spellings is correct. Hence the following mis-spellings ${ }^{2}$ :

Does all these sound vaguely familiar?

A local singer has contributed [sic] his new album to these group of farmers.

All these happened as the Prime Minister said.

All these frozen water eventually ends up in the ocean.

On the other hand, we also find:

In both of this different career paths that I chose..

We can only travel up and down this places by punt.

.. especially in this struggling times.

Most of the indentured labourers were from this two regions.

Similarly, vocabulary often follows Fiji English. For example, the word 'bury' is used to mean not only 'inter', but also 'reclaim (land)' and 'apply a poultice', because all three senses are included in the meaning of the Fijian word buluta.

Such mistakes have led some people to comment on how the standard of English in the Fiji media has gone down (e.g. veteran journalist Matt Wilson, cited in Robie, 2004, p. 247), and others to publish books on correct English specifically designed for speakers of Fiji English (e.g., Pene, 2003). ${ }^{3}$ What many people do not realise, however, is that that these mistakes have their origin in Fiji English, and that Fiji English arose in, and is perpetuated by, an educational system that forbids or discourages the use of vernaculars. When Fijian children are punished for speaking their own language and forced to speak 'English' long before they are capable of doing so, what they end up speaking is a language that is in many respects fundamentally Fijian, with only the form of the words giving it a superficial resemblance to English. 
It may be argued that the Fiji English of the media is more comprehensible to the local people than Standard English would be, and should therefore be encouraged. I would agree - but would take this argument to its logical conclusion: that if the media are to be comprehensible to the people of Fiji, they should use the languages of the people of Fiji, which are Fijian and Fiji Hindi. The main problem with this suggestion is that speakers of Fijian (and even more so speakers of Fiji Hindi) are not highly literate in their own language, as I will argue in the next section.

\section{Limited literacy in Fijian}

Official figures for 'literacy' in Fiji are always well over 90 per cent, but typically no indication is given as to how literacy is measured, or indeed in which language. Literacy is, of course, not an absolute but a matter of degree: in any language there are those who are highly skilled in reading and writing, those who are unskilled, and various levels in between. There is also a difference between active and passive literacy. In New Zealand, for example, most people are highly actively literate: they use literacy frequently every day in reading newspapers, books, notices, advertisements, etc and in writing notes, diaries, memos, shopping lists, and so on. For Fijian speakers, however, while it is true that most can read and write Fijian, they use this literacy very little. For them, literacy is largely passive and infrequent. They may read the Bible and hymn-book, or a newspaper, and write the occasional letter, but very little else. And if they do write diaries or notes or shopping lists, they usually do this in English, because they have not been taught to use their literacy in Fijian as an active tool.

Fijian speakers do not expect to find Fijian written in public notices, or anywhere in the public domain. For example, the vehicle registration letters CI, CU, and DA (all of which have been used in the past ten years) spell words with meanings in Standard Fijian which are, if not quite obscene, certainly indelicate. In a country with real literacy, they would have been omitted from the sequence so as not to cause offence - but not in Fiji. Similarly, the acronym for Canadian Airlines International, painted boldly on containers that are frequently seen being hauled round Fiji's roads, is an obscenity (corresponding to the English four-letter word beginning with ' $\mathrm{f}$ ') - and yet I have never heard anyone comment on it. Basically, Fijian speakers do not view their language as one that is written in public, and are surprised on those rare occasions when it is so used. 
One of the consequences of this limited literacy is that Fijian speakers tend to be poorly informed about national politics - which unfolds largely in English, and is reported mostly in that language. I have already argued in this journal (Geraghty, 2001) that the sad events of 2000 might have been avoided, or at least their impact reduced, if Fijian villagers had been better informed. Recent research by demographer Dr Mili Kaitani suggests that one of the reasons why so many Fijians are caught in a poverty trap is because they are not aware of the help that is available: 'Fijians do not want to read the papers, they are not interested in watching English television programs, they are not interested in listening to the radio except for music, they do not listen to the news and the talkback shows that are important' (Sunday Times 27 February 2005 , p. 6). While this is something of an exaggeration, it should prompt Fijian-speaking workers in the media to consider how well they are serving the Fijian-speaking public by continuing to write only in English.

Another problem with promoting media in Fijian is that Fijian speakers (including journalists) tend to have some negative views of their own language, and about their own competence in it, again largely as a result of the education system. They believe that Fijian is simply not suitable for anything outside the village, and that any Fijian sentence is much longer than its English equivalent. These beliefs have been reinforced by the variety of Fijian usually taught in schools, Old High Fijian, which was based on the poor Fijian spoken by English-speaking ministers and in which the Bible is translated, which is indeed impoverished in vocabulary and long-winded (Geraghty, 2004). Many judge themselves to be inadequate speakers of Fijian, simply because they do not know all the archaic words and expressions that constitute most of what is taught in school. Nevertheless, it is true that the general standard of Fijian vocabulary is going down, particularly in urban areas.

\section{Improving literacy}

I have argued above that the educational system promotes literacy in English at the expense of literacy in Fijian and Fiji Hindi, with the result that many people are 'quarter-literate', that is, semi-literate in both their vernacular and English. One obvious solution is to do more to promote first-language literacy in schools, so that children have a solid foundation in their own language before attempting to learn a second language. Rather than the current fad for 'English'-language kindergartens, which will only serve to damage 
children's English as well as their vernacular, English should only be introduced when the child has a good grasp of their mother tongue, perhaps around the seventh year.

In today's Fiji, English is not actually taught at schools. Children acquire it (very imperfectly) in the playgrounds and classrooms, and what is taught is largely remedial - attempting to counter the influence of Fiji English. English should be taught methodically through the medium of the child's first language, and in a way that anticipates the problems that Fijian-speakers will encounter in learning English, which are not the same as those encountered by speakers of other languages. For Fiji, this would be a radical departure, but it would be in line with the way languages are taught all over the world, and the result would be an improvement in the standard of literacy in both languages.

\section{Media that serve the people}

Fiji's colonial government from around 1930 attempted to solve what it perceived as the problem of multilingualism by making the mountain come to Mohammed - that is, by requiring the Fijian-speaking population to learn English as a condition of their benefiting from government services, including even basic education. The present government, although largely in the hands of Fijian speakers, continues this policy - and so, sadly, do most of the media.

In the same way that Fiji's 1997 constitution made the bold move of requiring that all citizens of Fiji be offered government services in a language they understand, it would be an equally bold move if those involved in the media in Fiji also decided to offer the public their wares in a language they all understand. It would require breaking away from the shackles of Fiji's colonial past, and indeed its colonial present, but in the long run would result in a better informed public - which is surely one of the main raisons d'être of the media, anywhere in the world. ${ }^{4}$ 


\section{Notes}

1 This is not to imply that The Fiji Times is any more or less non-standard than any other newspaper in Fiji.

${ }^{2}$ All citations are from The Fiji Times, references available on request.

${ }^{3}$ Another veteran journalist to echo this view was the late Sir Len Usher, as witness this transcription of an interview published in The Fiji Times (3 November 1997): Times: What do you think of the standard of journalism in Fiji?

Sir Len: I think there is a lack of quality of English...

Further on in the transcription of the interview, we find Sir Len's point unwittingly borne out by the following exchange:

Times: What do you see in the future for yourself?

Sir Len: Well, that's in the wrath of the gods.

I would guess that Sir Len actually said 'in the lap of the gods', but the interviewer was unfamiliar with this expression, and so substituted an expression he/she was familiar with - perhaps from the popular computer game rather than reading Homer's Iliad - but which makes no sense.

${ }^{4}$ Expatriate media bosses and their local representatives have sometimes stated that vernacular media are not profitable. For radio this is certainly not the case, and for the print media and television, it has simply never been tried. As I have previously argued in this journal: 'If a serious commitment were made to produce a quality Fijian daily, I don't doubt that it would soon outsell all the English ones' (Geraghty, 2001, p. 167).

\section{References}

Douglas, Norman \& Ngaire Douglas (1987). Fiji handbook: Business and travel guide. Sydney: Pacific Publications.

Geraghty, P. (1984). Language policy in Fiji and Rotuma. In Milner, GB, DG Arms \&

P Geraghty, Duivosavosa - Fiji's languages: their use and their future (pp. 3284). Fiji Museum Bulletin 8.

Geraghty, P. (1997). The ethnic basis of society in Fiji. In Lal, Brij V \& Tomasi R Vakatora (Eds), Fiji Constitution Review Commission Research Papers, Vol 1, Fiji in Transition (pp 1-23).Suva: School of Social and Economic Development, University of the South Pacific, 1-23.

Geraghty, P. (2000). Fiji Pidgin English. In Lal, Brij V \& Kate Fortune, The Pacific Islands: An encyclopedia ( $\mathrm{p} 75$ ). University of Hawaii Press.

Geraghty, P. (2001). Talking the wrong talk. Pacific Journalism Review 7(1):164-7. Geraghty, P. (2004). Foreigner talk to exonorm: translation and literacy in Fiji. In Fenton, Sabine (Ed), For better or for worse: translation as a tool for change in the South Pacific (pp 172-206), Manchester: St Jerome Press.

Mangubhai, F. \& F. Mugler (2003). The language situation in Fiji. Current Issues in Language Planning 4(3):367-459. http://www.multilingual-matters.net/cilp/004/ cilp0040367.htm 
THE INDIGENOUS PUBLIC SPHERE

Pene, F. (2003). Write it right. Suva: Institute of Education, The University of the South Pacific.

Robie, D. (2004). Mekim nius: South Pacific media, politics and education. Suva: USP Book Centre.

Siegel, J. (1987). Language contact in a plantation environment: A sociolinguistic history of Fiji. Studies in the Social and Cultural Foundations of Language. Cambridge: Cambridge University Press.

Dr Paul Geraghty is associate professor in linguistics with the University of the South Pacific's Department of Literature and Language. This commentary is a revised version of a talk presented at the Journalism Education Association (JEA) conference in Suva, Fiji, on 7 December 2004. The author is grateful to France Mugler for helpful comments, and to David Robie for encouraging him to publish his thoughts. 